\title{
Fish predation and the structure of the sea urchin Paracentrotus lividus populations in the NW Mediterranean
}

\author{
Enric Sala*, Mikel Zabala \\ Departament d'Ecologia, Facultat de Biologia, Universitat de Barcelona, Avda. Diagonal 645, E-08028 Barcelona, Spain
}

\begin{abstract}
Large differences in the sea urchin Paracentrotus lividus (Lamarck) population structure have been observed in the NW Mediterranean. Differences have been attributed to removal of predatory fish through human fishing activities. This study attempted to determine the effect of predation by fishes on sea urchin population structure. Three infralittoral areas $(2$ within a marine reserve with a high density of predatory fish, and 1 within an unprotected area with a low density of predatory fish) were studied to compare population structure differences attributable to differing fish predation pressure. P. lividus populations were 3 to $4 \times$ denser and predation rates were $\sim 5 \times$ lower in the unprotected site than in the protected sites. Within the reserve, fish accounted for $100 \%$ of the predation. $P$. lividus individual mean size was lower within the protected sites than in the unprotected site. Size-frequency distributions showed a negative exponential pattern for $P$. lividus within the reserve, and a bimodal pattern outside the reserve. The urchins showed a crevice-dwelling behaviour in response to the intense predation in the marine reserve. Within the reserve, $P$. lividus population structure appears to be determined by predation by fish. In contrast, in the unprotected area, where the predation rate is much lower. $P$. lividus population structure appears to be determined by recruitment rate. We suggest that a recent increase in $P$. lividus abundance on infralittoral rocky bottoms in the NW Mediterranean, where urchins are not harvested, is caused by human fishing activities. Since $P$. Iividus is the major benthic herbivore in the NW Mediterranean, fishing level may, due to cascading effects, determine the structure of benthic infralittoral communities.
\end{abstract}

KEY WORDS: Fishing · Fish predation · Population structure - Sea urchins - Paracentrotus

\section{INTRODUCTION}

The edible sea urchin Paracentrotus lividus (Lamarck) is distributed throughout the Mediterranean Sea and along the European coasts of the North Atlantic, and it is generally restricted to shallow waters, where it can attain very high densities (Kempf 1962, Harmelin et al. 1980, 1981, Verlaque 1987). In infralittoral communities of the Western Mediterranean, $P$. lividus is a key species that controls the dynamics of seaweeds and seagrasses, by eliminating, when at high densities, the erect stratum of brown algae and seagrasses and thereby inducing the forma-

•E-mail: esala@grn.es tion of a bare patch dominated by encrusting algae (Kempf 1962, Vukovic 1982, Verlaque \& Nedelec 1983, Verlaque 1987). Factors suggested to determine the structure of Mediterranean P. lividus populations include: recruitment (Azzolina 1988, Lozano et al. 1995), diseases (Azzolina 1988), and physical factors (Turon et al. 1995). Predation may be important in controlling $P$. lividus abundances (Verlaque 1984, Boudouresque et al. 1992), and several organisms have been identified as predators of $P$. lividus (see Savy 1987). However, few experimental studies have been performed to ascertain the effect of predation on $P$. lividus populations (but see Dance \& Savy 1987).

Predation has been implicated as an important process affecting the structure of sea urchin populations 
(Duggins 1980, Tegner \& Dayton 1981, Breen et al. 1982, Tegner \& Levin 1983, McClanahan \& Muthiga 1989, McClanahan \& Shafir 1990, McClanahan 1992, McClanahan et al. 1994). Predation also mediates sea urchin behavior such as the choice of habitat by juveniles (Tegner \& Dayton 1977. Cameron \& Schroeter 1980, Tegner \& Levin 1983) and adults (Ogden et al. 1973, Breen et al. 1982), diel foraging patterns (Ebling et al. 1966, Nelson \& Vance 1979, Carpenter 1984, Dance \& Savy 1987, Levitan \& Genovese 1989) or aggregating behavior (Bernstein et al. 1983, McClanahan 1988, but see Elner \& Vadas 1990). The availability of refuges may, however, mediate the predation as sea urchin distribution and grazing may be restricted to areas near shelter (Ebling et al. 1966, Ogden et al. 1973, Carpenter 1984, Levitan \& Genovese 1989. McClanahan \& Kurtis 1991)

The main goal of this study was to determine the causes of the recent increase in sea urchin abundance in the NW Mediterranean Sea in some localities where it is not harvested (Verlaque 1987). Observations suggested that sea urchin abundance could be negatively related to fish abundance. Differences in fish abundance, and especially the sea urchin predators Diplodus sargus, Diplodus vulgaris and Coris julis, are related to levels of fishing (García-Rubies \& Zabala 1990, Garcia-Rubies 1996). Therefore, we hypothesized that Paracentrotus lividus population increases are caused by predator reductions due to fishing. In this study we present findings from a comparative survey of areas with different abundances of predatory fish in the NW Mediterranean and an experiment to test stated hypotheses concerning predation. The hypotheses examined were: (1) predation rates on $P$. lividus should be higher at the unfished versus the fished sites, (2) predation should decrease with increasing individual size, and thus (3) predation by fish should determine the abundance and population structure of P. lividus.

\section{MATERIAL AND METHODS}

Study sites. The study was carried out in the Medes Islands Protected Area (NE Spain, NW Mediterranean Sea) (Fig. 1) The Protected Area (93.2 ha), where fishing is prohibited, is located $1 \mathrm{~km}$ offshore opposite the town of L'Estartit $\left(42^{\circ} 16^{\prime} \mathrm{N}, 03^{\circ} 13^{\prime} \mathrm{E}\right)$ and encompasses a few small islands (total surface area less than 20 ha). The study was conducted on bottoms of big limestone boulders, between 5 and $10 \mathrm{~m}$ deep

Preliminary observations and stomach content analysis have shown the fish species Diplodus sargus (L.), Diplodus vulgaris (E.G. Saint-Hilaire) and Coris julis (L.), and the muricid gastropod Trunculariopsis

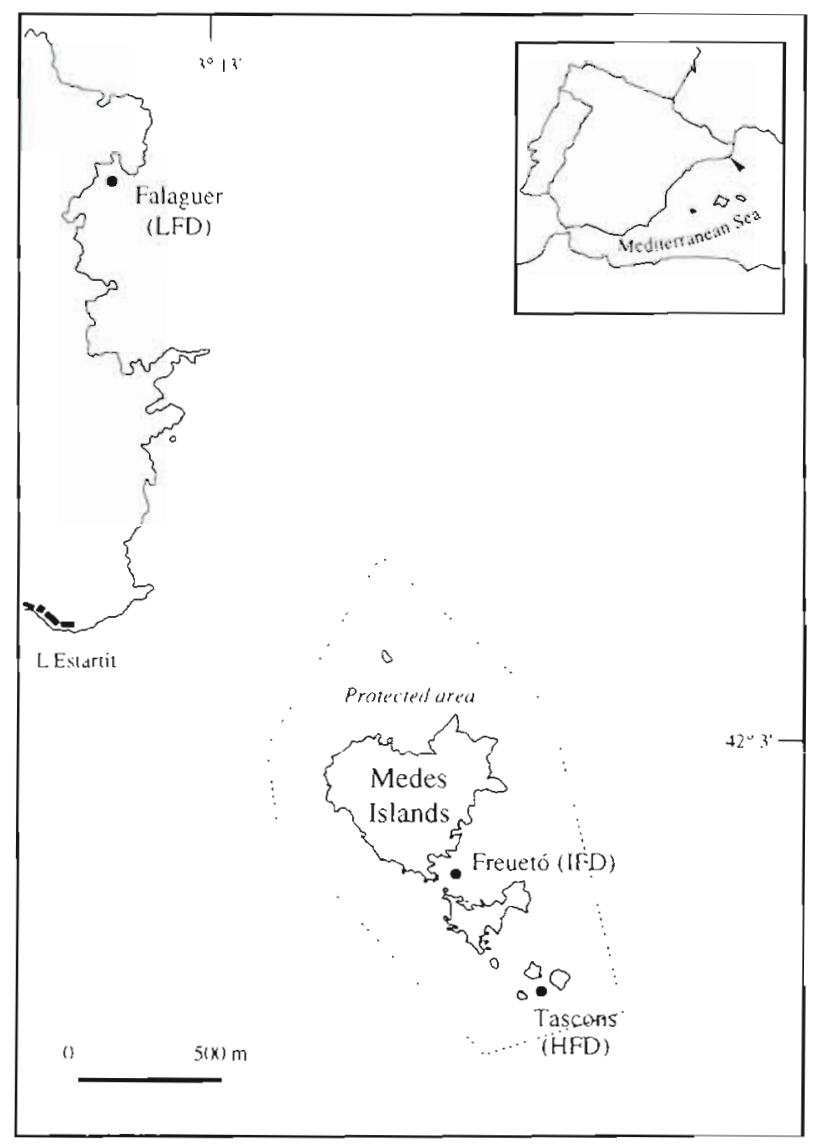

Fig. 1. Location of study sites, inside [Tascons (HFD) and Freueto (IFD)] and outside [Falaguer (LFD)] the Medes Islands Protected Area, NE Spain, NW Mediterranean Sea. Dotted line represents the limits of the Medes Islands Protected Area, where all fishing is prohibited. HFD: high fish density site; IFD: intermediate fish density site; LFD: low fish density site

trunculus (L.) to be the main consumers of Paracentrotus lividus. The fish assemblages have been studied in detail by García-Rubies \& Zabala (1990) and by García-Rubies (1996). Taking these studies as references, 3 sites were chosen which, other important factors (depth, topography, orientation, water motion) remaining unchanged, reflect differences in both the density and composition of predator guilds. Two sites were placed in the Protected Area (Tascons and Freuetó) and 1 outside the reserve (Falaguer) (Fig. 1, Table 1). A preliminary survey showed that variations in sea urchin abundance and population structure were not significant from place to place along the unprotected shore near the reserve (authors' unpubl. data), and thus only 1 site outside the reserve was chosen for this study. Tascons presented the highest fish density and is hereafter referred to as the HFD (High Fish Density) site; Freuetó had intermediate fish densities and is 
Table 1 Major predatory fish species in sampling sites. Data are $\mathrm{kg}$ wet mass $\mathrm{ha}^{-1}$ (mean $\pm \mathrm{SD}$ ). Data from García-Rubies (1996). HFD: high fish density site; IFD: intermediate fish density site; LFD: low fish density site

\begin{tabular}{|lccc|}
\hline \multicolumn{3}{c}{ Protected area } & Unprotected area \\
& HFD & IFD & \\
\hline Sparidae & & & \\
$\begin{array}{l}\text { Diplodus sargus } \\
\text { Diplodus vulgaris } \\
\text { Labridae } \\
\text { Coris julis }\end{array}$ & $419.9 \pm 126.8$ & $272.2 \pm 59.8$ & $74.3 \pm 4.9$ \\
& $15.2 \pm 2.1$ & $142.8 \pm 67.7$ & $7.8 \pm 3.3$ \\
\hline
\end{tabular}

and February 1993 to isolate seasonal variability, and in August 1993 and August 1994 to isolate interannual variability. The sampling procedure (5 transects per site and date) was also carried out on vertical walls without apparent spatial refuges, within (at the HFD site) and outside (at the LFD site) the Protected Area in order to compare the density of urchins with the density at the bottom with boulders, where refuge availability is much greater.

hereafter referred to as the IFD (Intermediate Fish Density) site; and Falaguer had the lowest fish density and is hereafter referred to as the LFD) (Low Fish Density) site. As an example of differences in fish biomass between sites, the biomass of the fish species Diplodus sargus was $\sim 6$ times greater at the HFD site than at the LFD site (García-Rubies 1996).

Predator guild. Prior to the experiment and during the first sampling period observations on predation and test condition were made in order to determine predators and their effect on sea urchin tests. Observed predators frequently included various species of Sparidae and Labridae fish which are known predators of Paracentrotus lividus (Quignard 1966, Rosecchi 1985, Khoury 1987, Sala 1996). These fishes consume the sea urchins in their entirety, including the test (Savy 1987). Therefore, missing tests indicated predation by fish. On the other hand, a single perforation in the test indicated predation by gastropods, probably Trunculariopsis trunculus. This gastropod makes a single circular perforation on the test (up to $1 \mathrm{~cm}$ diameter), then consumes the interior of the urchin, leaving the test (spines detached) and the Aristotle's lantern intact.

Structure of Paracentrotus Iividus populations. The abundance and population size-structure of Paracentrotus lividus inhabiting large boulders were studied by SCUBA-diving along quantitative transects $(50 \mathrm{~m} \times$ $1 \mathrm{~m}$ each), between 5 and $10 \mathrm{~m}$ deep, at each study site. Within each transect, $P$. lividus $>1 \mathrm{~cm}$ in diameter were counted and their diameter (test without spines) was measured with a caliper. In the first $20 \mathrm{~m}^{2}, P$. Iividus $>1 \mathrm{~cm}$ were counted and measured, but they were only counted in the following $30 \mathrm{~m}^{2}$. The diameters were grouped in size classes of $1 \mathrm{~cm}$, and in subtransects of $10 \mathrm{~m}^{2}$. Additionally, the urchin's level of exposure to predators was indicated: (1) cryptic: sheltered, within crevices or beneath the boulders, not exposed to carnivorous fishes; or (2) exposed: without physical protection, totally exposed to carnivorous fishes. The sampling (5 transects per site and date) was repeated in May, August and November 1992
The above method used to census adult populations of Paracentrotus lividus is not suitable for smaller individuals (recruits, diameter $<1 \mathrm{~cm}$ ), because they are very inconspicuous. Therefore, the recruits were sampled by scraping off all organisms, including encrusting algae, with a hammer and chisel (Boudouresque 1971), in $250 \mathrm{~cm}^{2}$ quadrats. Samples were fixed in formalin (5\% in seawater) and carefully examined under a stereomicroscope. The number and diameter of every juvenile found was recorded. Recruit sampling was undertaken monthly, from March 1992 to February 1993 ( $n=8$ quadrats per site and date, from March 1992 to September 1992; $\mathrm{n}=4$ quadrats per site and date, from October 1992 to February 1993),

Predation experiment. Predation was tested within (HFD) and outside (LFD) the Protected Area, by tethering Paracentrotus lividus from 4 size classes (diameters of $2-3 \mathrm{~cm}, 3-4 \mathrm{~cm}, 4-5 \mathrm{~cm}$, and $5-6 \mathrm{~cm}$ ) to lines using a tagging method described by McClanahan \& Muthiga (1989). P. lividus were perforated through the oral and aboral sections of the test with a hypodermic needle and threaded with monofilament line $(0.25 \mathrm{~mm})$. This technique has little detrimental effect on sea urchins (McClanahan \& Muthiga 1989). Ten individuals were attached at $2 \mathrm{~m}$ intervals onto $20 \mathrm{~m}$ transect lines, which were laid over large boulders, between 5 and $10 \mathrm{~m}$ deep. Six transect lines, 15 individuals of each size class and a total of 60 urchins per site, were simultaneously placed within each of the 2 sites. Lines were visited every 24 h for a $3 \mathrm{~d}$ period in July 1995. Only 3 urchins (2.5\% of the total) died because of tagging [intact bleached test with spine missing; not related to seastar Marthasterias glacialis (L.) predation] and were removed from the data analysis.

In the data analysis, average survival rates were calculated for each site and size class. The last surviving day of each experimental Paracentrotus lividus was recorded and used as the unit of measure. The total length of the experiment was $3 \mathrm{~d}$, and therefore $100 \%$ survival would produce a mean of $3 \mathrm{~d}$ whereas $100 \%$ 
mortality during the first day would produce a mean survival rate of $0 \mathrm{~d}$. Predation was then calculated as the total length of the experiment ( 3 d) minus the survival rate in days. Relative predation intensity (PI) was then calculated by dividing predation intensity by 3 . The predation rates reported here should be regarded as an estimate of maximum PI because sea urchins had restricted mobility and could not always hide in crevices or beneath boulders

Data analysis. Data from the 3 sites were pooled for comparisons of densities, size structure and level of exposure of Paracentrotus lividus populations. Prior to performing parametric tests, the assumptions of normality and homoscedasticity were tested by Kolmogorov-Smirnov and Bartlett tests, respectively. When assumptions were not met, a rank-transformation of the data was carried out (Potvin \& Roff 1993). Differences in density between sampling sites and times were analyzed by 2 -way ANOVA. To test diflerences in mean diameter between sites and sampling times, a 2-way ANOVA on rank-transformed data was performed. Differences in $P$. lividus size distribution and level of exposure were analyzed by frequency analysis $\left(\chi^{2}\right)$.

To test for differences in recruitment rate during the year between the 3 sites, a 2-way ANOVA on ranktransformed data was performed. To estimate recruit mortality rates, we fitted a simple exponential function. of abundance of recruits counted in scrapings $(N)$ as a function of time. An instantaneous mortality rate (Margalef 1974) was calculated.

$$
N_{t}=N_{0} \mathrm{e}^{-z t} \text {, or } \ln \left(N_{t}\right)=\ln \left(N_{0}\right)-z t
$$

where $N_{0}$ and $N_{t}$ are the number of individuals at the beginning and at the end of the time period, $t$ is time (in mo), and $z$ is the instantaneous mortality rate. $N_{0}$ was the number of recruits in August, when recruitment peaked and the number of recruits was the highest. The null hypothesis that rates of recruit mortality did not differ among sites was tested by comparing linear regressions of the number of urchin recruits surviving $(y)$ vs time in months $(x)$ by analysis of covariance (ANCOVA) (Zar 1984). A regression line was computed for each site. The slopes of these regression lines were compared since they represent the actual mortality rate. Values of the dependent variable were $\ln (y+1)$ transformed to satisfy the equation referred to above. Similar use of ANCOVA to compare mortality rates was reported by Moran et al. (1984), Etter (1989) and Witman \& Sebens (1992)

To test for differences in experimental Paracentrotus lividus survival between sites and sizes, 2-way ANOVA on rank-transformed data and Tukey tests (Zar 1984) were performed using the survival rates obtained from the predation experiment.

\section{RESULTS}

\section{Population structure on bottoms with boulders}

Densities of Paracentrotus lividus for all sampling times and sites are summarized in Table 2. Comparison of densities across sites by 2 -way ANOVA showed a highly significant effect of the main factors (site: $F=$ 227.40, $\mathrm{df}=2, \mathrm{p}<0.001$; time: $F=12.19$, df $=5, \mathrm{p}<$ 0.001 ), as well as of the interaction factor between site and time $(F=6.33, \mathrm{df}=10, \mathrm{p}<0.001)$, indicating different temporal trends in the 3 sites. For most sampling dates, the unprotected (fished) coast (LFD site) had the greatest $P$. lividus density, followed by IFD and HFD, within the Protected Area (Table 2). P. lividus populations presented seasonal fluctuations in density at IFD (ANOVA, $F=3.83, \mathrm{df}=3, \mathrm{p}<0.05$ ). No interannual variations (from 1992 to 1994, data from August) in density were observed for the 2 sites within the Protected Area (HFD and IFD), but density increased significantly at LFD from 1992 to 1993, and then decreased in 1994 (Table 2; ANOVA, $F=6.80, \mathrm{df}=2$, $p<0.01$ )

For most sampling times, the Paracentrotus lividus test size-frequency distribution at LFD was bimodal: the first mode was formed by urchins from 1 to $2 \mathrm{~cm}$, and the second was formed by urchins of 4 to $6 \mathrm{~cm}$ (Fig. 2). However, at HFD the P. lividus size-frequency distribution showed a negative exponential curve for most sampling times (Fig. 2). IFD exhibited an intermediate pattern, close to a negative exponential, but with a lower mode at 5 to $6 \mathrm{~cm}$ (Fig. 2). Size-frequency distribution showed significant seasonal and interannual variations at the 3 sampling sites $\left(\chi^{2}\right.$ frequency analysis, $p<0.001$ ). Likewise, size-frequency distributions of $P$. lividus were different between sampling sites at all sampling times $\left(\chi^{2}, \mathrm{p}<0.001\right)$.

The unprotected habitat had larger test sizes than the Medes Islands Protected Area (hereafter referred to as MIPA) (Table 3; ANOVA, $F=37.69$, df $=2, p<$

Table 2. Paracentrotus lividus. Number of sea urchins $(>1 \mathrm{~cm}$ diameter) per $10 \mathrm{~m}^{2}$ (mean $\pm \mathrm{SE}$ ) at each site and sampling time. HFD: high fish density site; IFD: intermediate fish den-

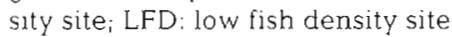

\begin{tabular}{|lccc|}
\hline Sampling date & HFD & IFD & LFD \\
\hline May 1992 & $28.4 \pm 5.6$ & $23.9 \pm 2.4$ & $84.6 \pm 5.4$ \\
Aug 1992 & $28.6 \pm 5.5$ & $43.3 \pm 4.8$ & $91.6 \pm 8.3$ \\
Nov 1992 & $18.8 \pm 2.2$ & $42.1 \pm 2.9$ & $97.1 \pm 7.1$ \\
Feb 1993 & $18.0 \pm 4.7$ & $40.0 \pm 5.4$ & $118.9 \pm 12.9$ \\
Aug 1993 & $40.0 \pm 6.2$ & $45.0 \pm 6.2$ & $160.5 \pm 12.0$ \\
Aug 1994 & $51.6 \pm 11.9$ & $33.0 \pm 4.2$ & $100.4 \pm 7.7$ \\
Average & $28.2 \pm 2.3$ & $37.9 \pm 1.9$ & $107.3 \pm 4.5$ \\
\hline
\end{tabular}


0.001 ). Mean diameter of Paracentrotus lividus showed a significant increase from HFD to LFD (Table 3). Within sites, mean diameter showed temporal variations (ANOVA, df $=4, F=40.00, p<$ 0.001 ) : it decreased from 1992 to 1993 at HFD and LFD, and increased from 1993 to 1994 at HFD and IFD. Likewise, the interaction term in the 2-way ANOVA was significant $(F=8.90, \mathrm{df}=8, \mathrm{p}<$ 0.001 ), indicating that the pattern of temporal variation of mean diameter was different at the 3 sites.

\section{Predation pressure and refuge utilization}

The density of Paracentrotus lividus was lower on vertical walls than on boulders both within and outside the MIPA (Table 4). The density of $P$. lividus on vertical walls was higher in the unprotected area than within the MIPA ( $t$-test, $p<$ 0.001 ).

The general pattern of sea urchin exposure to predators was that the smallest individuals were generally cryptic, while exposed urchins usually belonged to larger size classes (Fig, 3). Furthermore, the higher the fish abundance, the lower the proportion of exposed sea urchins $\left(\chi^{2}\right.$, $p<0.001)$. The mean diameter of the smallest sea urchins in exposed positions increased from LFD to HFD $\left(\chi^{2}, p<0.001\right)$. The results also showed seasonal variations in the proportions of the level of exposure among size classes at HFD and $\operatorname{IFD}\left(\chi^{2}, p<0.001\right)$ : the proportion of exposed urchins was higher in fall (Fig. 3)

Table 3. Paracentrotus lividus. Mean diameter in mm ( \pm SE) of sea urchin $>1 \mathrm{~cm}$. HFD: high fish density site; IFD: intermediate fish density site; LFD: low fish density site. ND: no data available

\begin{tabular}{|lccc|}
\hline Sampling date & HFD & IFD & LFD \\
\hline May 1992 & $31.9 \pm 0.8$ & $39.6 \pm 1.3$ & $35.7 \pm 0.5$ \\
Aug 1992 & $29.9 \pm 0.6$ & $30.0 \pm 0.9$ & $34.5 \pm 0.6$ \\
Nov 1992 & $32.5 \pm 1.0$ & $30.7 \pm 0.7$ & $33.1 \pm 0.8$ \\
Feb 1993 & $26.8 \pm 1.3$ & $33.6 \pm 1.0$ & $31.8 \pm 0.7$ \\
Aug 1993 & $23.4 \pm 0.6$ & $29.9 \pm 0.8$ & $30.9 \pm 0.4$ \\
Aug 1994 & $30.2 \pm 0.9$ & $36.1 \pm 1.4$ & ND \\
Total & $29.2 \pm 0.3$ & $32.2 \pm 0.4$ & $33.0 \pm 0.2$ \\
& & & \\
\hline
\end{tabular}
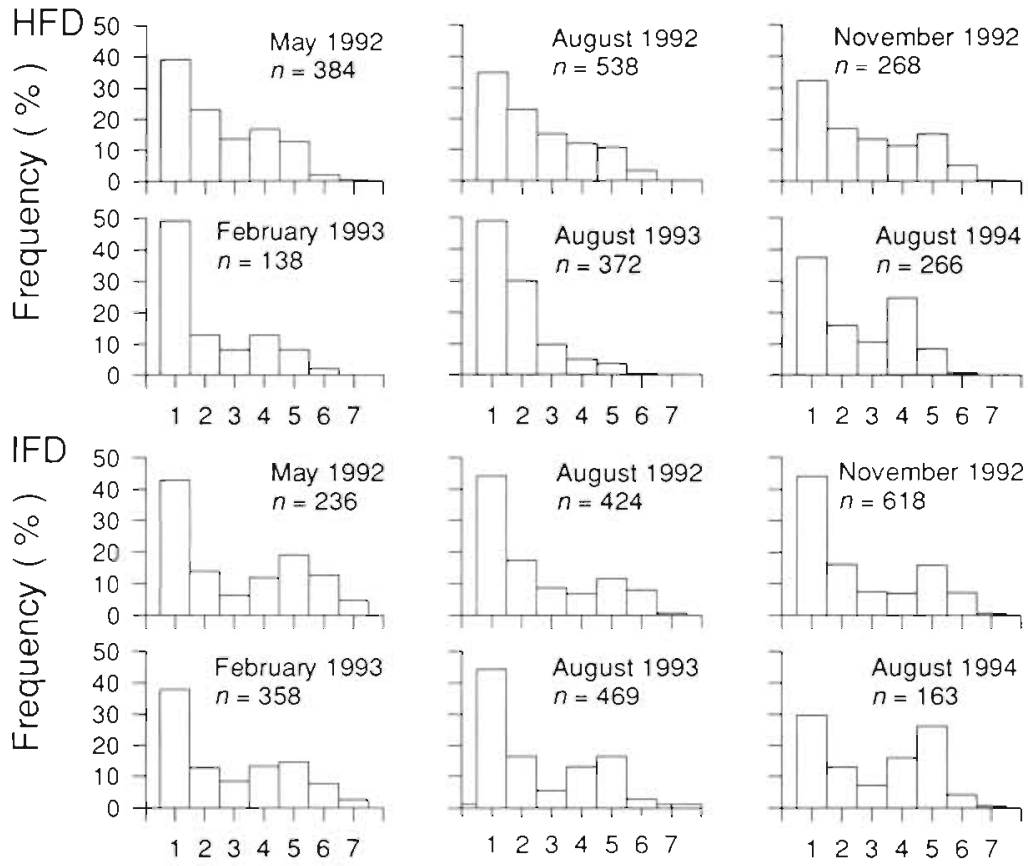

1234567

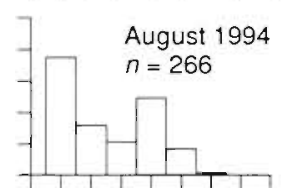

1234567
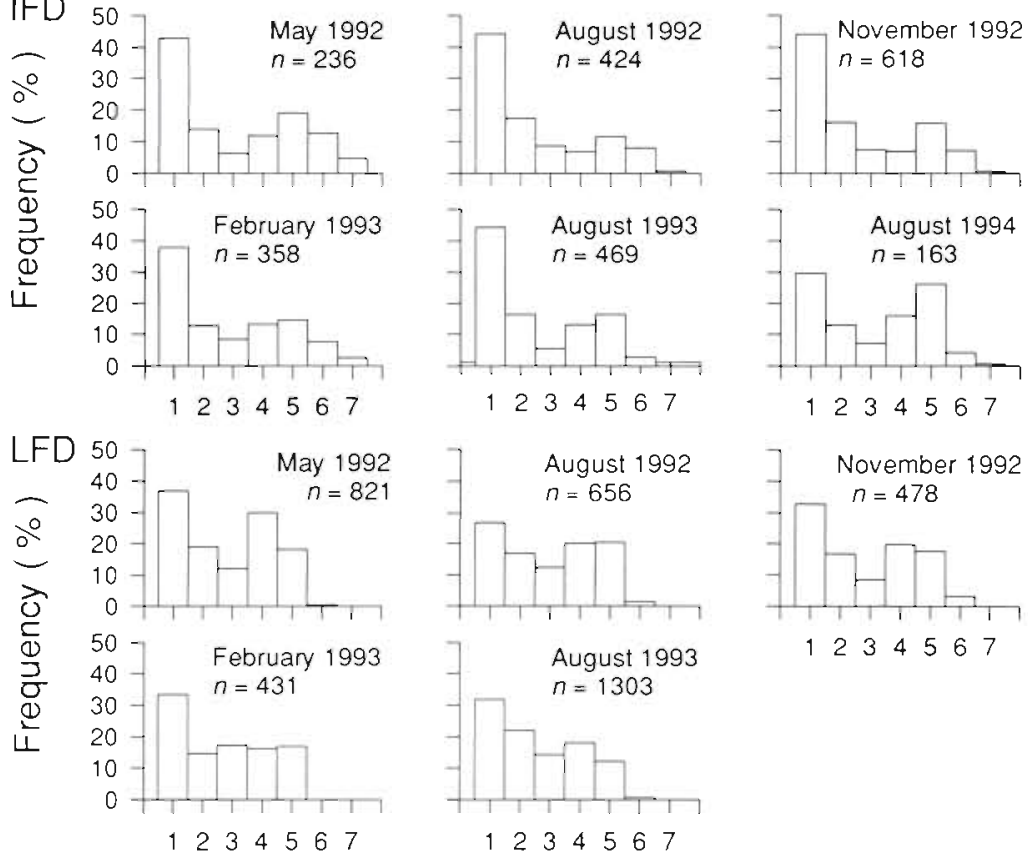

$\begin{array}{lllllll}1 & 2 & 3 & 4 & 5 & 6 & 7\end{array}$

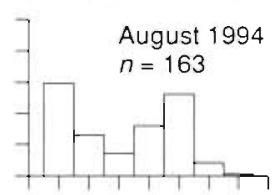

1234567
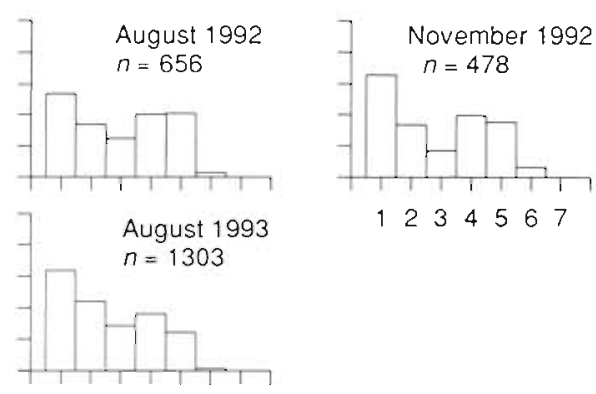

1234567

\section{Size class}

Fig. 2. Paracentrotus lividus. Sea urchin $(>1 \mathrm{~cm})$ test size frequency from May 1992 to August 1994. Size class: $1=1-2 \mathrm{~cm}, 2=2-3 \mathrm{~cm}, 3=3-4 \mathrm{~cm}, 4=$ $4-5 \mathrm{~cm}, 5=5-6 \mathrm{~cm}, 6=6-7 \mathrm{~cm}, 7=7-8 \mathrm{~cm}$. HFD: high fish density site; IFD: intermediate fish density site; LFD: low fish density site

Table 4. Paracentrotus lividus. Number of sea urchins $(>1 \mathrm{~cm})$ per $10 \mathrm{~m}^{2}$ (mean $\pm \mathrm{SE}$ ) on vertical walls and boulders within and outside the Medes Islands Protected Area, from 1992 to 1994. Data correspond to density in August. $t$-test analysis, $\cdots p<0.001$

\begin{tabular}{|c|c|c|c|}
\hline & Boulders & Walls & $\mathrm{p}$ \\
\hline \multicolumn{4}{|c|}{ Protected area } \\
\hline 1992 & $34.6 \pm 3.9$ & $8.0 \pm 0.2$ & $\cdots$ \\
\hline 1993 & $42.4 \pm 4.4$ & $8.2 \pm 0.1$ & $\cdots$ \\
\hline 1994 & $42.3 \pm 6.5$ & $19.1 \pm 0.9$ & $\cdots$ \\
\hline \multicolumn{4}{|c|}{ Unprotected area } \\
\hline 1992 & $91.6 \pm 8.3$ & $37.1 \pm 0.7$ & $\cdots$ \\
\hline 1993 & $160.5 \pm 12.0$ & $45.5 \pm 0.8$ & $\cdots$ \\
\hline 1994 & $100.4 \pm 7.7$ & $28.7 \pm 0.5$ & $\cdots$ \\
\hline
\end{tabular}



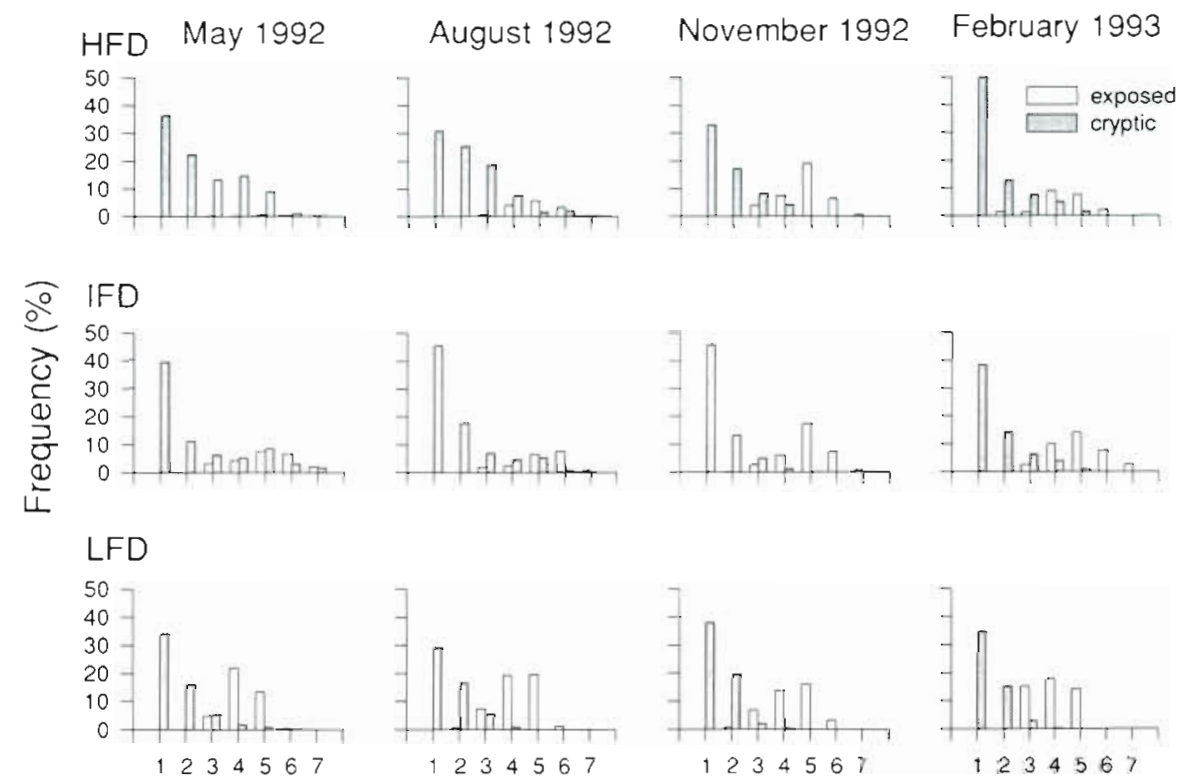

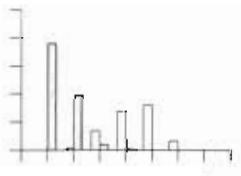

1234567

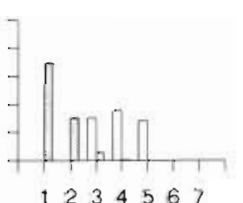

1234567

Size class

\section{Recruitment}

Paracentrotus lividus recruited to all sites, but recruitment rate differed at the 3 sites (Fig. 4; 2-way ANOVA, $F=5.23, \mathrm{df}=2, \mathrm{p}<0.01$ ). Recruitment exhibited a marked seasonality ( 2 -way ANOVA, $F=18.20$, $\mathrm{df}=10, \mathrm{p}<0.001$ ), with a single peak in August at the 3 sites (Fig. 4). Likewise, the interaction term was significant $(F=2.92, \mathrm{df}=20, \mathrm{p}<0.001)$, indicating that the trend of seasonal variation in the abundance of recruits was different at the 3 sites. Mean maximum density of recruits was 3650 ind. $\mathrm{m}^{-2}$ at HFD, 1876 ind. $\mathrm{m}^{-2}$ at IFD, and 1160 ind. $\mathrm{m}^{-2}$ at LFD. Mortality rates $(z)$ were 0.75 at HFD $\left(r^{2}\right.$ of the regression $\left.=0.92\right), z=0.63\left(r^{2}=0.94\right)$ at IFD, and $z=0.82\left(\mathrm{r}^{2}=0.95\right)$ at LFD (Table 5, Fig. 5). The pattern revealed by analysis of covariance was that recruit mortality rate did not differ among sites ( $p$ $>0.05$; Table 5, Fig. 5).

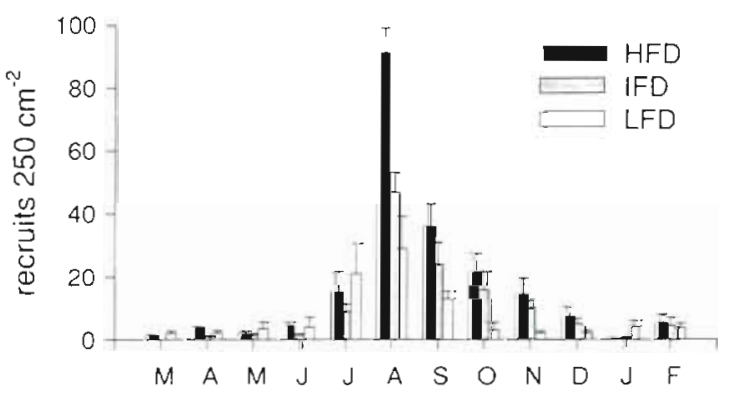

Fig. 4. Paracentrotus lividus. Recruit abundance (mean 250 $\mathrm{cm}^{-2} \pm \mathrm{SE}$ ) from March 1992 to February 1993. HFD: high fish density site; IFD: intermediate fish density site; LFD: low fish density site
Fig. 3. Paracentrotus lividus. Level of sea urchin exposure among size classes at the 3 sites, with respect to season. Cryptic: within crevices or beneath the boulders, not exposed to predatory fish; exposed: over the boulders, totally exposed to predatory fish. Size classes as in Fig. 2. HFD: high fish density site; IFD: intermediate fish density site; LFD: low fish density site

\section{Predation experiment}

Comparison of the survival rates across sites by 2way ANOVA showed a highly significant effect of the main factors (site: $F=31.01$, df $=1, \mathrm{p}<0.001$, size: $F=$ 10.62, $\mathrm{df}=3, \mathrm{p}<0.001)$. MIPA had rates of predation $(\mathrm{PI}=0.36) \sim 5$ times higher than the fished site (LFD) $(\mathrm{PI}=0.07)$. Survival rates of Paracentrotus lividus were lower at HFD for all urchins, especially for individuals with a diameter of 2 to $5 \mathrm{~cm}$ (Fig. 6). The interaction be-

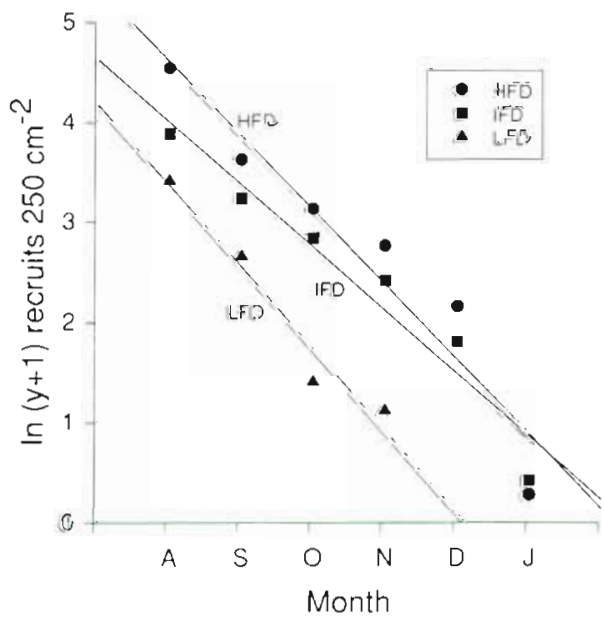

Fig. 5. Paracentrotus lividus. Mortality of recruits at the 3 study sites. HFD: high fish density site; IFD: intermediate tish density site; LFD: low fish density site. Linear regression analysis was performed on each site; regression equations are presented in Table 5. The slopes of the regression lines indicate the actual mortality rate 
Table 5. Paracentrotus lividus. Regression lines of recruit survivorship vs time. The slope represents the actual mortality rate. HFD: high fish density site; IFD: intermediate fish density site; LFD: low fish density site. ${ }^{p} p<0.05, \cdots p<0.01$

\begin{tabular}{|c|c|c|c|}
\hline Site & Regression equation $^{d}$ & $\mathrm{p}$ & $r^{2}$ \\
\hline HFD & $y=5.341-0.746 x$ & " & 0.919 \\
\hline IFD & $y=4.620-0.629 x$ & $\cdot \cdot$ & 0.942 \\
\hline LFD & $y=4.171-0.816 x$ & $\cdot$ & 0.953 \\
\hline
\end{tabular}

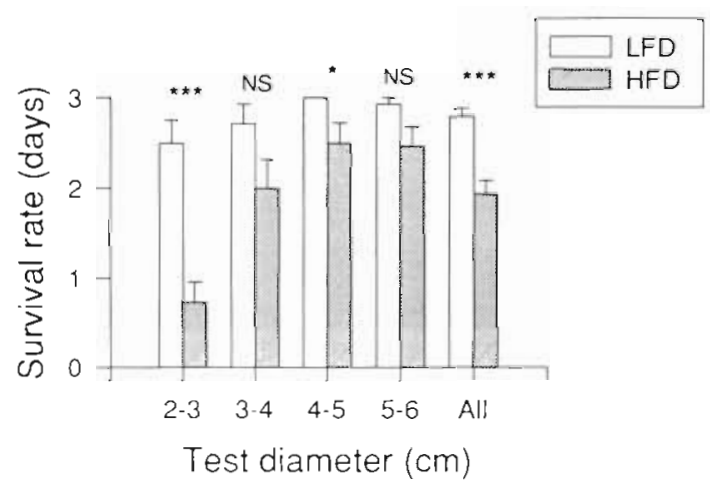

Fig. 6. Paracentrotus Ividus. Predation experment. Average sea urchin survival rate $( \pm S E)$ for a $3 \mathrm{~d}$ period within sites and sizes (test diameter). Tukey test, NS = non-significant, $\cdot p<$ $0.05, \cdots p<0.001$

tween site and size was also significant $(F=2.75, \mathrm{df}=3$, $p<0.05$ ), indicating different predation trends in the 2 sites. In the fished site (LFD) there were no variations in the predation rate among size classes. In the MIPA predation rate was higher for the smallest size-class ( 2 to $3 \mathrm{~cm}$ diameter) (Tukey test, $\mathrm{p}<0.001$ ), although predation was detected within all test sizes (Fig. 6).

Predation was always due to fish ( $100 \%$ of total predation) within the MIPA (HFD). In the fished area (LFD), predation by fish represented the $57 \%$ of total, whereas the gastropod Trunculariopsis trunculus caused $43 \%$ of the mortality. At LFD, fish predation occurred only among the smallest size class $(2$ to $3 \mathrm{~cm}$ diameter), whereas larger urchins were only consumed by the gastropods.

\section{DISCUSSION}

Results indicate distinct differences between unprotected and protected sites for most measured variables. The lower densities of adult Paracentrotus lividus within the MIPA relative to the unprotected area are a reflection of the high predation rates at these sites. The relation between predator abundance and sea urchin abundance has been reported previously in other temperate (e.g. Estes \& Palmisano 1974, Estes et al. 1978, Wharton \& Mann 1981, but see Elner \& Vadas 1990) and tropical habitats (e.g. Hay 1984, McClanahan \& Muthiga 1989), and also recently in the Mediterranean (Boudouresque et al. 1992, San Martin 1995, Sala 1996). In the last $30 \mathrm{yr}$, an increase in P. lividus abundances has been reported in the NW Mediterranean (Verlaque 1987). Verlaque suggested that abundance of juvenile sea urchin in certain habitats, and the overfishing of littoral fish and crustaceans could explain this phenomenon. Our results are consistent with this hypothesis

The decrease in Paracentrotus lividus mean diameter within the MIPA may have 2 causes, i.e. (1) the effect of fish predation and/or (2) the high settlement of recruits in 1992. (1) Effect of fish predation: Juvenile $P$. lividus that survive early mortality are able to escape efficiently from predation within shelters. However, when growing, a larger size reduces the ability to occupy small shelters, leaving sea urchins more exposed to predation (Dotan 1990, McClanahan \& Kurtis 1991). As shown in the predation experiment, fish also feed on medium-size urchins, hence predation on them within the HFD may cause the differences observed between sites. Finally, large tests provide a form of predatory escape (Connell 1972, Tegner \& Dayton 1981, McClanahan \& Muthiga 1989, San Martin 1995). Our results are consistent with this trend, and large individuals were consumed at a lower rate during the predation experiment, and only large sea urchins were found on exposed places on sites with high fish abundance. (2) Important settlement in August 1992, relative to later years (Lozano et al. 1995) (which also caused a decrease in population mean diameter at LFD): Since $P$. lividus exhibits a growth rate of approximately $1 \mathrm{~cm} \mathrm{yr}^{-1}$ in the first few years (Azzolina 1988), the large input of individuals in August 1992 induced a conspicuous increase in the abundance of the immediately larger size class (1 to 2 cm in diameter) in August 1993 (Fig 2).

A problem arose from contradictory results from the different samplings performed. On the one hand, Paracentrotus lividus recruited to all sites, but settlement was higher at HFD than at LFD. On the other hand, recruit mortality did not differ among sites. A higher increase in sea urchin populations at HFD, relative to LFD, would be expected. However, the population density of $P$. hividus did not increase at HFD from 1992 to 1993 although recruitment was high. Thus, juvenile plus adult mortality had to be much higher at HFD than at LFD (Fig. 7). Fish predation, as shown in the predation experiment, may control the abundance of 
HFD

LFD

\section{LARVAE}

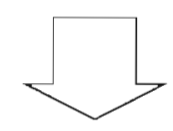

RECRUITS<smiles>C1CCCC1</smiles>

JUVENILES

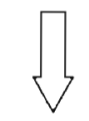

ADULTS

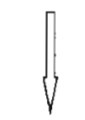

ADULTS

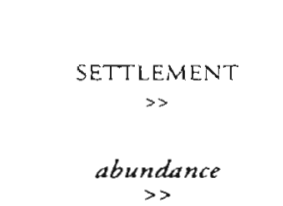

RECRUIT MORTALITY

$=$

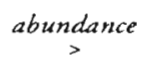

$>$

$$
\begin{gathered}
\text { POST-RECRUIT } \\
\text { MORTALITY } \\
>> \\
\text { abundance } \\
<
\end{gathered}
$$

ADULT MORTALITY $\gg$

abundance

$<$

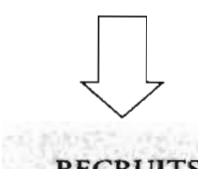

RECRUITS
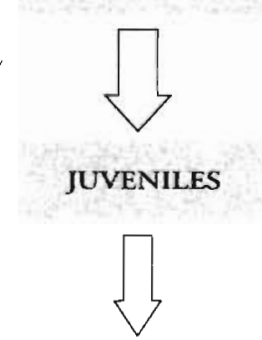

ADULTS

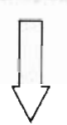

ADULTS
Fig. 7. Paracentrotus lividus. Model of temporal changes in sea urchin abundance in 2 sites differing in fish predation pressure. HFD: high fish density site (high fish predation); LFD: low fish density site (low fish predation). Width of the arrows represents the transfer of individuals between compartments

post-recruits and adults at HFD. Furthermore, the recruit mortality rate calculated is an apparent mortality rate, which may be lower than the real mortality rate, since recruitment is not punctual in time:

Apparent mortality rate (between $t_{x}$ and $\left.t_{x+1}\right)=$

Real mortality - Recruitment (between $t_{x}$ and $t_{x+1}$ )

Thus real recruit mortality rate may yet be higher within the MIPA.

The Paracentrotus lividus size-frequency distribution reinforces the above suggestion that fish predation may exert control on population structure. Along the unprotected coast there was a bimodal distribution of size frequencies: the first mode was due to annual recruitment, and the second mode may be explained by a strong recruitment which occurred a few years ago. Variation of recruitment among years has also been suggested to explain bimodal patterns of size in other sea urchin populations (Underwood \& Denley 1984, Underwood \& Fairweather 1989). However, at HFD the size-frequency distribution approximated a negative exponential curve. It appears that control of small-size individual density by predatory fish may determine the abundance of large-size indi- viduals, irrespective of recruitment rate interannual changes.

The location of juvenile Mediterranean sea urchins in shelters (crevices, holes, etc.) may be a strategy to adapt to intense predation (Harmelin \& Duval 1983, Verlaque 1984, 1987). This crevice-dwelling behavior is common in other echinoid species in the presence of predators (Ogden et al. 1973, Tegner \& Dayton 1977, Nelson \& Vance 1979, Breen et al. 1982, Tegner \& Levin 1983, Dotan 1990, McClanahan \& Kurtis 1991). In the study area, the frequency of sea urchins exposed to predators was negatively related to the abundance of predatory fish. However, not only juvenile sea urchins, but also large adults up to $7 \mathrm{~cm}$ in diameter were located in these spatial refuges. The decrease in the density of Paracentrotus lividus on vertical walls suggests this is not an optimal substrate for sea urchins, because of the topography and exposure to predators. Azzolina (1988) noted that distance from nurseries is another factor that may determine the abundance of $P$. lividus. Refuge availability thus appears to be an important factor in determining the abundance of $P$. lividus. $P$. lividus were found on all substrata on rocky bottoms in the unprotected area, where physical factors (mainly surge) are not limiting. However, within the MIPA most urchins were restricted to shelters. A high structural complexity, in terms of high availability of crevices, allowed sea urchins to escape from predators, resulting in the existence of small barren areas within the boulder zone. Our results suggest that refuge availability mediates the effect of fish predation on P. lividus. This effect may have important consequences for benthic community structure, as the availability of shelter may be a sufficient condition for the creation of areas of barren habitat (Andrew 1993).

The seasonal variations in the frequency of exposed sea urchins within the MIPA suggest seasonal variations in fish feeding pressure on sea urchins. Some predatory fish (Sparidae) exhibit seasonal variations in abundance within the MIPA, being more abundant in summer (García-Rubies 1996). The higher proportion of exposed sea urchins in fall might reflect a decrease in the abundance of major predatory fish, or changes in their diet.

In summary, predation by fish appears to determine Paracentrotus lividus (1) abundance, (2) mean size, (3) size-frequency distribution, and (4) behaviour. The maintenance of the patterns described over time supports our hypotheses about the role of fishes in determining P. lividus abundance and population structure, despite the seasonal and interannual changes that occur at the study sites. The relative stability in the structure of $P$. lividus populations within the MIPA contrasts with the interannual changes induced by the 
variability in the recruitment rate at LFD. We suggest that recruitment rate, rather than predation, determines the structure of $P$. lividus populations on the unprotected coast. In the MIPA, in contrast, fish predation appears to be the single most important factor controlling $P$. lividus population structure.

Other factors, like epidemic diseases, may be able to regulate Paracentrotus lividus populations in the NW Mediterranean. The bald sea urchin disease, which occurred along the French coast in the 1980s, strongly reduced $P$. lividus abundance (Boudouresque et al. 1981, Azzolina 1987, 1988). A survey carried out 12 yr after the outbreak of the disease showed that $P$. Iividus populations had recovered completely (Zabala et al. unpubl. data). However, the phenomenon had a narrow spatial range, limited almost entirely to the PortCros National Park and adjacent waters (Azzolina 1987), and thus this recovery process should not be confounded with the increase attributed to a lack of predators for the rest of the NW Mediterranean littoral.

Despite the relative diversity of predators (Savy 1987), we suggest that a small number of species may be responsible for controlling Paracentrotus lividus distribution. Our observations and data suggest that the Sparida Diplodus sargus is the greatest predator of adult $P$. lividus and may be considered a key species within the infralittoral zone. However, the Sparida Diplodus vulgaris and the Labrida Coris julis may be important predators on the earlier phases of $P$. lividus. Nevertheless, mortality rates of $P$. lividus recruits may not be due to fish predation alone, but also to several mobile epifaunal organisms that inhabit the algal community: caprellids, crabs, shrimps, isopods and polychaetes (Harrold et al. 1991). Predation by the gastropod Trunculariopsis trunculus, unexpected and not previously reported, requires additional research.

Our results provide evidence that the reduction of predators (in this instance, littoral fish) has resulted in a Paracentrotus lividus population explosion on NW Mediterranean infralittoral rocky bottoms on which the urchins are not harvested (Verlaque 1987). Although this study is a local one, observations made on many NW Mediterranean protected and unprotected areas suggest that this is a common pattern. Further research is required to investigate the regulation of $P$. lividus populations, when predator densities and post-settlement mortalities are low and settlement is high, to determine their expansion limits.

It has been shown that levels of fishing pressure may determine the composition and structure of fish assemblages at several spatial scales (Koslow et al. 1988, Russ \& Alcala 1989, García-Rubies \& Zabala 1990, Francour 1991, 1994, Roberts \& Polunin 1991, Grigg 1994, McClanahan 1994b, García-Rubies 1996). Furthermore, the increase in fish abundance within non- fished areas (due to prohibition or remote geographical situation) may have striking effects on benthic communities (Hay 1984, McClanahan 1989, 1992, 1994a, b, c, McClanahan \& Muthiga 1989, McClanahan \& Shafir 1990, Boudouresque et al. 1992, Witman \& Sebens 1992, Sala 1996). In the Medes Islands, prohibition of fishing has cascading effects that result, in this instance, in a lower abundance of the sea urchin Paracentrotus lividus. Since $P$. lividus is the major benthic herbivore in the NW Mediterranean (Verlaque 1987), the structure of the rocky infralittoral communities may be related to fishing intensity.

Acknowledgements. We thank V. Alvà, E. Ballesteros, P. Ferrer, C. Gadea, J. Garrabou, B. Hereu, J.M. Llenas, E. Pola, M. Ribes, and D. Tàpies for many hours spent counting, collecting and tethering sea urchins. We are grateful to C. F. Boudouresque for continuous encouragement throughout the study. and for interesting discussions. We also thank $A$. Gordoa, $M$. Harmelin-Vivien, E. Macpherson, X. Turon, M. Verlaque and an anonymous referee for valuable comments on the manuscript. Special thanks to T. R. McClanahan for discussions, suggestions and for introducing us to the predation experiments. Thanks to L. Polo and the Universitat de Girona's Laboratori de Biologia Vegetal for laboratory facilities. This research was supported by a Diputació de Girona predoctoral grant to E.S., and by project number PCC $68003 / 9$ of the Direcció General de Pesca of the Generalitat de Catalunya.

\section{LITERATURE CITED}

Andrew NL (1993) Spatial heterogeneity, sea urchin grazing, and habitat structure on reefs in temperate Australia. Ecology 74:292-302

Azzolina JF (1987) Evolution a long terme des populations de l'oursin comestible Paracentrotus lividus dans la baie de Port-cros (Var, France). In: Boudouresque CF (ed) Colloque international sur Paracentrotus lividus et les oursins comestibles. GIS Posidonie Publ, Marseille, p 257-269

Azzolina JF (1988) Contribution à l'étude de la dynamique des populations de l'oursin comestible Paracentrotus lividus (Lmck). Croissance, recrutement, mortalite, migrations. PhD thesis, Université d'Aix-Marseille II

Bernstein BB, Schroeter SC, Mann KH (1983) Sea urchin (Strongylocentrotus droebachiensis) aggregating behavior investigated by a subtidal multifactorial experiment. Can J Fish Aquat Sci 40:1975-1986

Boudouresque CF (1971) Méthodes d'étude qualitative et quantitative du benthos (en particulier du phytobenthos). Téthys 3:79-104

Boudouresque CF, Caltagirone A, Lefevre JR, Rico V, Semroud $\mathrm{R}$ (1992) Macrozobenthos de la réserve naturelle de Scandola (Corse, Méditerranée nord-occidentale). Analyse pluriannuelle de 'l'effet réserve'. In: Olivier J, Gerardin N, Jeudy de Grissac A (eds) Impact économique des espaces côtiers protégés de Méditerranée. Sécrétariat du MEDPAN Publ, Ajaccio, p 15-20

Boudouresque CF, Nedelec E, Shepherd SA (1981) The decline of a population of the sea urchin Paracentrotus lividus in the bay of Port-Cros (Var, France). Rapp Comm Int Mer Médit 27:223-224

Breen PA, Carson TA, Foster JB, Stewart EA (1982) Changes in subtidal community structure associated with British 
Columbia sea otter transplants. Mar Ecol Prog Ser 7:13-20

Cameron RA, Schroeter SC (1980) Sea urchin recruitment: effect of substrate selection on juvenile distribution. Mar Ecol Prog Ser 2:243-247

Carpenter RC (1984) Predator and population density control of homing behaviour in the Caribbean echinoid Diadema antillarum. Mar Biol 82:101-108

Connell JH (1972) Community interactions on marine rocky intertidal shores. Annu Rev Ecol Syst 3:169-192

Dance C, Savy S (1987) Predation on Paracentrotus Lvidus by Marthasterias glacialis: an in-situ experiment at Port-Cros (France, Mediterranean). Posidonia Newsletter 1:35-41

Dotan A (1990) Population structure of the echinoid Heterocentrus mamillatus (L.) along the littoral zone of southeastern Sinai. Coral Reefs 9:75-80

Duggins DO (1980) Kelp beds and sea-otters: an experimental approach. Ecology 61:447-453

Ebling FJ, Hawkins AD, Kitching JA, Muntz L, Pratt VM (1966) The ecology of Lough ine XVI. Predation and diurnal migration in the Paracentrotus community. J Anim Ecol. 35:559-566

Elner RW, Vadas RL (1990) Inference in ecology: the sea urchin phenomenon in the Nurthwestern At.antic. Am Nat 136:108-125

Estes JA, Palmisano JF (1974) Sea otters: their role in structuring nearshore communities. Science 185:1058-1060

Estes JA, Smith NS, Palmisano JF (1978) Sea otter predation and community organization in the Western Aleutian Islands, Alaska. Ecology 59:822-833

Etter RJ (1989) Life history variation in the intertidal snail Nucella lapillus across a wave exposure gradient. Ecology $70: 1857-1876$

Francour P (1991) The effect of protection level on a coastal fish community at Scandola, Corsica. Rev Ecol Terre Vie $46: 65-81$

Francour $P$ (1994) Pluriannual analysis of the reserve effect on ichthyofauna in the Scandola natural reserve (Corsica, Northwestern Mediterranean). Oceanol Acta 17:309-317

García-Rubies A (1996) Estudi ecologic de les poblacions de peixos litorals sobre substrat rocós a la Mediterrània Occidental: Efecte de la fondaria, el substrat, l'estacionalitat i la protecció. PhD thesis, Universitat de Barcelona

García-Rubies A, Zabala M (1990) Effects of total fishing prohibition on the rocky fish assemblages of Medes Islands marine reserve (NW Mediterranean). Sci Mar 54:317-328

Grigg RW (1.994) Effects of sewage discharge, fishing pressure and habitat complexity on coral ecosystems and reef fishes in Hawain. Mar Ecol Prog Ser 103:25-34

Harmelin JG, Bouchon C, Duval C. Hong JS (1980) Les échinodermes des substrats durs de l'Ile de Port-Cros, Parc National (Méditerranée nord-occidentale). Eléments pour un inventaire quantitatif. Trav Sci Parc Nation Port-Cros 6: $25-38$

Harmelin JG, Bouchon C, Hong JS (1981) Impact de la pollution sur la distribution des échinodermes des substrats durs en Provence (Méditerranée nord-occidentale). Téthys 10:13-36

Harmelin JG, Duval C (1983) Localisation et dissémination des jeunes de l'oursin Sphaerechinus granularis (Lamarck\} en Méditerranée. Rapp Comm Int Mer Médit 28: $267-269$

Harrold C, Lisin S, Light KH, Tudor S (1991) Isolating settlement from recruitment of sea urchins. J Exp Mar Biol Ecol 147:81-94

Hay ME (1984) Patterns of fish and urchin grazing on Caribbean coral reefs: are previous results typical? Ecology $65: 446-454$
Kempf M (1962) Recherches d'écologie comparée sur Paracentrotus lividus (Lmk.) et Arbacia lixula (L.). Rec Trav Stn Mar Endoume Fac Sci Mars 25:47-116

Khoury C (1987) Ichtyofaune des herbiers de posidonies du Parc National de Port-Cros: composition. éthologie alimentaire et rôle dans le réseau trophique. PhD thesis, Université d'Aix-Marseille II

Koslow JA, Hanley F, Wicklund R (1988) Effects of fishıng on reef fish communities at Pedro Bank and Port Royal Cays, Jamaica. Mar Ecol Prog Ser 43:201-212

Levitan DR, Genovese SJ (1989) Substratum-dependent predator-prey dynamics: patch reefs as refuges from gastropod predation. J Exp Mar Biol Ecol. 130:111-118

Lozano J, Galera J, López S, Turón X, Palac'n C, Morera G (1995) Biological cycles and recruitment of Paracentrotus lividus (Lamarck) (Echinodermata: Echinoidea) in two contrasting habitats. Mar Ecol Prog Ser 122:179-191

Margalef R (1974) Ecología. Ed Omega, Barcelona

McClanahan TR (1988) Coexistence in a sea urchin guild and its implications to coral reef diversity and degradation. Oecologia 77:210-218

McClanahan TR (1989) Kenyan coral reef-associated gastropod fauna: a comparison between protected and unprotected reefs. Mar Ecol Prog Ser 53:11-20

McClanahan TR (1992) Resource utilization, competition and predation: a model and example from coral reef grazers. Ecol Model 61:195-215

McClanahan TR (1994a) Harvesting in an uncertain world impact of resource competition on harvesting dynamics. Ecol Model 80:21-26

McClanahan TR (1994b) Kenyan coral reef lagoon fish: effects of fishing, substrate complexity, and sea urchins. Coral Reefs 13:231-241

McClanahan TR (1.994c) A coral reef ecosystem-fisheries model: impacts of fishing intensity and catch selection on reef structure and processes. Ecol Model 80:1-19

McClanahan TR, Kurtis JD (1991) Population regulation of the rock-boring sea urchin Echinometra mathaei (de Blainville). J Exp Mar Biol Ecol 147:121-146

McClanahan TR, Muthiga NA (1989) Patterns of predation on a sea urchin, Echinometra mathaei (de Blainville), on Kenyan coral reefs. J Exp Mar Biol Ecol 126:77-94

McClanahan TR, Nugues M, Mwachireya S (1994) Fish and sea urchin herbivory and competition in Kenyan coral reef lagoons: the role of reef management. J Exp Mar Biol Ecol 184:237-254

McClanahan TR, Shafir SH (1990) Causes and consequences of sea urchin abundance and diversity in Kenyan coral reef lagoons. Oecologia 83:362-370

Moran ML, Fairweather PG, Underwood AJ (1984) Growth and mortality of the predatory intertidal whelk Morula marginalba; the effects of different species of prey. J Exp Mar Biol Ecol 75:1-17

Viclson BV, Vance RR (1979) Diel foraging patterns of the sea urchin Centrostephanus coronatus as a predator avoidance strategy. Mar Biol 51:251-258

Ogden JC., Brown RA. Salesky N (1973) Grazing by the echinoid Diadema antillarum Philippi: formation of halos around West Indian patch reefs. Science 182:715-717

Potvin C, Roff DA (1993) Distribution-free and robust statistical methods: viable alternatives to parametric statistics? Ecology $74: 1617-1628$

Quignard JP (1966) Recherches sur les Labridae (Poissons téléostéens, perciformes) des côtes éuropéennes. Systématique et biologie. Nat Monpel Ser Zool 5:7-247

Roberts CM, Polunin NVC (1991) Are marine reserves effective in management of reef fisheries? Rev Fish Biol Fish 1:65-91 
Rosecchi E (1985) Ethologie alimentaire des Sparidés: Diplodus annularis, Diplodus sargus, Diplodus vulgaris, Pagellus erythrinus, Sparus aurata du golfe de Lion et des étangs palavasiens. PhD thesis, Université Sciences et Technique du Languedoc, Montpellier

Russ GR, Alcala AG (1989) Effects of intense fishing pressure on an assemblage of coral reef fishes. Mar Ecol Prog Ser $56: 13-27$

Sala $E$ (1996) The role of fishes in the organization of a Mediter ranean sublittoral community. PhD thesis, Université d'Aix-Marseille II

San Martin GA (1995) Contribution à la gestion des stocks d'oursins: étude des populations et transplantations de Paracentrotus lividus à Marseille (France) et production de Loxechinus albus à Chiloe (Chili, Pacifique). PhD thesis, Université d'Aix-Marseille II

Savy S (1987) Les predateurs de Paracentrotus lividus (Echinodermata). In: Boudouresque CF (ed) Colloque International sur Paracentrotus lividus et les oursins comestibles. GIS Posidonie Publ, Marseille, p 413-423

Tegner MJ, Dayton PK (1977) Sea urchin recruitment patterns and implications of commercial fishing. Science 196: $324-326$

Tegner MJ, Dayton PK (1981) Population structure, recruitment and mortality of two sea urchins (Strongylocentrotus franciscanus and $S$. purpuratus) in kelp forest. Mar Ecol Prog Ser 5:255-268

Tegner MJ, Levin LA (1983) Spiny lobsters and sea urchins: analysis of a predator-prey interaction. J Exp Mar Biol Ecol 73:125-150

Turon X, Giribet G, López S, Palacín C (1995) Growth and population structure of Paracentrotus lividus (Echinodermata: Echinoidea) in two contrasting habitats. Mar Ecol Prog Ser 122:193-204

This article was submitted to the editor
Underwood AJ, Denley EJ (1984) Paradigms, explanations, and generalizations in models for the structure of intertidal communities on rocky shores. In: Strong Jr DR (ed) Ecological communities: conceptual issues and the evidence. Princeton University Press, Princeton, p $151-180$

Underwood AJ, Fairweather PJ (1989) Supply-side ecology and benthic marine assemblages. TREE 4:16-20

Verlaque M (1984) Biologie des juvéniles de l'oursin Paracentrotus lividus (Lamarck): séléctivité du broutage et impact de l'espece sur les communautés algales de substrat rocheux en Corse (Méditerranée, France). Bot Mar 27. 401-424

Verlaque M (1987) Relations entre Paracentrotus lividus (Lamarck) et le phytobenthos de Méditerranée occidentale. In: Boudouresque CF (ed) Colloque international sur Paracentrotus lividus et les oursins comestibles. GIS Posidonie Publ, Marseille, p 5-36

Verlaque M, Nédélec $H$ (1983) Note préliminaire sur les relations biotiques Paracentrotus lividus (Lmk.) et herbier de posidonies. Rapp Comm Int Mer Médit 28:157-158

Vukovic A (1982) Florofaunistic changes in the infralitoral zone after the sea urchin Paracentrotus lividus (L.) population explosion. Acta Adriat 23:237-241

Wharton WG, Mann KH (1981) Relationship between destructive grazing by the sea urchin, Strongylocentrotus droebachiensis, and the abundance of American lobster, Homarus americanus, on the Atlantic coast of Nova Scotia. Can J Fish Aquat Sci 38:1339-1349

Witman JD, Sebens KP (1992) Regional variation in fish predation intensity: a historical perspective in the Gulf of Maine. Oecologia 90:305-315

Zar JH (1984) Biostatistical analysis, 2nd edn. Prentice-Hall, Englewood Cliffs, NJ

Manuscript first received: February 1, 1996

Revised version accepted: May 25, 1996 